\title{
CAROLE PATEMAN E A CRÍTICA FEMINISTA DO CONTRATO*
}

\section{Luis Felipe Miguel}

Universidade de Brasília (UnB), Brasília - DF, Brasil. E-mail: luisfelipemiguel@gmail.com

DOI: http//dx.doi.org/10.17666/329303/2017

Se definimos os primórdios do feminismo como vinculados à obra de Mary Wollstonecraft (2001 [1792]), podemos caracterizá-lo, em grande medida, como um movimento por inclusáo política. Tratava-se de estender às mulheres os direitos que o pensamento liberal atribuía aos homens e que a Revolução Francesa prometia conceder a todos os homens. O eixo das reivindicaçóes era o acesso à esfera pública e um conjunto de direitos que eram necessários para que tal acesso pudesse ocorrer, como os direitos à educaçáo e à propriedade. Não por acaso, a face mais visível do movimento

* Este artigo foi produzido no âmbito da pesquisa "Teoria democrática, dominação política e desigualdades sociais", apoiada pelo CNPq com uma bolsa de Produtividade em Pesquisa. Agradeço a leitura prévia e os comentários de Flávia Biroli e de Regina Dalcastagnè.

Aprovado em 04/07/2016 feminista do século XIX é o sufragismo: a luta pelo direito de voto sintetiza a exigência de igualdade política entre mulheres e homens.

O que marca o pensamento de Wollstonecraft como feminista é a vinculação, que ela faz com veemência, entre a exclusão na esfera pública e a opressão no espaço privado; dito de outra forma, ela introduz a crítica à distinção público/privado, que será própria do feminismo até hoje. É possível dizer que o sufragismo venceu a batalha em relação à sua agenda específica - o direito de voto foi conquistado pelas mulheres, na maior parte dos regimes eleitorais, nas primeiras décadas do século XX. ${ }^{1}$ Mas tal vitória não foi acompanhada de uma redefinição das hierarquias no espaço doméstico ou da rediscussão das fronteiras entre público e privado.

$\mathrm{O}$ feminismo que reemerge na metade do século XX, cujo marco é a obra de Simone de Beauvoir (1949), apresenta uma aproximação diferente em relação à política. A política em sentido estrito 
é praticamente uma ausência. Em Beauvoir, assim como em Betty Friedan (2001 [1963]) ou Germaine Greer (1991 [1970]), para citar duas obras centrais do desencadeamento da chamada "segunda onda" do feminismo, o foco está na construção social da mulher e nos limites impostos à sua agência autônoma. São questóes eminentemente políticas, é claro, e o feminismo desde então contribui para forçar e redefinir os limites do que entendemos como política. Mas a atenção dada à política institucional e o diálogo com as tradiçóes da teoria política são praticamente nulos.

Neste momento, a denúncia do patriarcado, como forma de dominação política, é fortemente retórica e com reduzido desenvolvimento teórico, já que se julga que o império do patriarcado "é evidente, uma vez que se lembra que forças armadas, indústria, tecnologia, universidades, ciência, cargos políticos e finança - em suma, cada caminho para o poder dentro da sociedade, incluindo a força coercitiva da polícia, está inteiramente em mãos masculinas" (Millett, 2000 [1969], p. 25). O sexismo é apresentado "como raiz e paradigma das várias formas de opressão” (Daly, 1993 [1973], p. 56), e o estupro, como "modelo da construção de armas nucleares, racismo, pobreza causada pelo homem, contaminação química” (Idem, p. xvi). Em suma, grande parte da formulação feminista, até finais da década de 1970, passa ao largo da teoria política.

Só a partir de então começa a se formar uma teoria política feminista propriamente dita. Ela passa por uma revisão crítica dos pressupostos do pensamento político ocidental, em especial assinalando como a divisão entre as esferas pública e privada, naturalizada e assumida como incontestável, é crucial tanto para o estabelecimento do espaço da política tal como ele está constituído quanto para a exclusão das mulheres desse mesmo espaço. Longe de ser um acontecimento contingente, tal exclusão é condição necessária para e consequência inevitável da maneira como a política e as instituições são concebidas (Brennan e Pateman, 1979; Okin, 2013 [1979]; Elshtain, 1993 [1981]). A partir daí, o feminismo ressitua a discussão sobre os principais temas da teoria política - democracia, representação, justiça, cidadania, identidade - apresentando uma alterna- tiva crítica (ou, antes, um conjunto de alternativas críticas) às concepçôes hegemônicas.

É possível dizer que a obra que marca a chegada desse projeto a seu estágio maduro é $O$ contrato sexual, da cientista política britânica Carole Pateman (1988). Ela faz uma leitura em profundidade da tradição do pensamento político ocidental e apresenta uma reinterpretação feminista de um de seus elementos-chave, a noção de contrato social. Enquanto na narrativa contratualista, que dominou a filosofia política dos séculos XVII e XVIII e conheceu um revival a partir dos anos de 1970, o contrato é o instrumento que formaliza a igualdade civil, a inclusão da categoria "gênero" permite entendê-lo como definidor de assimetrias e exclusóes. Pateman avança na direção de uma crítica abrangente ao contrato, que para o pensamento liberal garante a possibilidade de cooperação social sem coerção, na medida em que se baseia em consentimentos voluntários e acordos mútuos, mas que ela descreve como produtor de padróes de submissão.

Neste artigo, apresento uma leitura abrangente da obra de Pateman, buscando identificar as contribuiçóes - significativas - que ela faz a uma ciência crítica da política. $\mathrm{Na}$ primeira seção, trato $\mathrm{da} \mathrm{Pa}$ teman "pré-feminista". Suas obras iniciais, embora não tenham uma preocupação focada nas relações de gênero, já indicam muitos dos temas que surgirão depois. $\mathrm{Na}$ segunda seção, debruço-me sobre $O$ contrato sexual, a obra em que a discussão sobre as desigualdades entre homens e mulheres encontra as discussóes anteriores da autora sobre o significado social do consentimento. Na terceira seção, discuto até que ponto a leitura de Pateman sobre o contrato serve para compreender as assimetrias de gênero nas sociedades contemporâneas.

\section{A democracia liberal como limite à autonomia}

A crítica de Carole Pateman aos limites do liberalismo é anterior à preocupação com as questóes de gênero. Sua obra pré-feminista já apresenta uma denúncia das formas naturalizadas de submissão presentes na sociedade, a começar por seu livro de estreia, o influente Participação e teoria democrática 
(Pateman, 1992 [1970]). Seu alvo são as democracias liberais vigentes no mundo ocidental, em que a promessa de soberania popular é reduzida à transferência de poder pelo voto. Ela anota a contradição entre o chamamento eventual à participação, no momento das eleiçóes, e o treinamento contínuo para a passividade e a obediência, nas relaçóes verticalizadas e autoritárias dominantes nos diferentes espaços da vida cotidiana - em particular, nas relaçóes de trabalho. Apoiando-se em Jean-Jacques Rousseau, em John Stuart Mill e no defensor da democracia industrial, G. D. H. Cole, ela propóe um modelo democrático renovado, em que as pessoas participam diretamente da tomada de decisóes que afetam seu dia a dia, como maneira tanto de ampliar sua autonomia quanto de qualificá-las para outras formas de intervenção política.

Há dois elementos, em Participação e teoria democrática, que sinalizam desdobramentos posteriores da reflexão de Pateman. O primeiro deles é que, embora não esteja preocupada com questóes de gênero e não dê atenção ao ambiente familiar, ela já póe em xeque a fronteira entre o público (o Estado, em que processos democráticos de decisão são aceitos e mesmo requeridos) e o privado (as empresas, nas quais é legítimo que impere o arbítrio do patrão). O segundo é a recusa a aceitar ao pé da letra as maneiras pelas quais a submissão é formalmente admitida como voluntária e, portanto, legítima. Ainda que, na democracia liberal, a participação no processo eleitoral seja compreendida como a aceitaçâo da autoridade que dele resulta, na ausência de condições para uma ação efetiva e esclarecida esses resultados são injustos e carentes de legitimidade.

É esse segundo ponto que organiza o livro seguinte de Pateman, no qual, embora ainda dando às questóes de gênero um estatuto secundário, ela estabelece o arcabouço geral do que será sua contribuição ao pensamento feminista. The problem of political obligation (Pateman, 1985 [1979]) apresenta um escrutínio crítico abrangente da visão liberal do contrato, indicando como o pressuposto de que relações contratuais são voluntárias e mutuamente benéficas funciona para que, por meio de contratos, formas de submissão de algumas pessoas a outras passem de ilegítimas a legítimas, de injustas a justas, de condenáveis a aceitáveis. O que seria do- minação e exploração torna-se, graças ao contrato, cooperação interindividual.

Seu foco, como o título já indica, é a "obrigação política": o que faz com que uns poucos mandem e os restantes devam obedecer. Como ela observa em outro momento, a noção liberal de indivíduos "naturalmente" livres e iguais revoluciona a discussão "sobre relaçóes de autoridade de todos os tipos; como e por que um indivíduo livre e igual pode, alguma vez, ser legitimamente governado por outra pessoa" (Pateman, 1989, p. 72). Para o contratualismo liberal, a única resposta possível é a obrigação autoassumida. $\mathrm{O}$ compromisso de obedecer a outro implica uma restrição à liberdade individual que "só é compatível com o postulado inicial de liberdade e igualdade se o indivíduo se coloca voluntariamente na relação. A relação de obrigação é justificada porque o indivíduo a criou para si mesmo, com completo conhecimento daquilo que ela envolve" (Pateman, 1985 [1979], p. 13). É a narrativa que está presente em Thomas Hobbes ou em John Locke: diante dos muitos problemas do estado de liberdade natural, em que não há autoridade estabelecida, as pessoas entendem que é necessária uma sociedade política e, por isso, decidem estabelecer um pacto que produz um governo e, simultaneamente, a obrigação de que todos obedeçam a ele.

Entre os muitos problemas que emergem da formulação contratualista, três se destacam. O primeiro é a maneira pela qual os indivíduos participantes do pacto transacionam suas liberdades, assinalando aquilo que, na teoria política, é chamado de "individualismo possessivo" (Macpherson, 1962): os direitos individuais são como propriedades, externas a cada pessoa e logo negociáveis. Há, assim, uma contradição entre o sistema jurídico fundado na noção de direitos inalienáveis e a ordem política que legitima uma autoridade que seria fruto da alienação de direitos. Pano de fundo tanto de The problem of political obligation quanto de $O$ contrato sexual, o tema foi tratado em artigo posterior de Pateman (2009 [2002]).

O segundo problema, central na discussão apresentada em $O$ contrato sexual, é o das exclusóes. $\mathrm{Nem}$ todos os indivíduos presentes no estado de natureza participam do pacto. Locke, por exemplo, assume uma exigência de racionalidade que lhe per- 
mite afastar crianças, mulheres e trabalhadores. A atribuição de racionalidade deficiente para os dois primeiros grupos estaria ancorada na sua imaturidade e na sua debilidade intelectual inata. No caso dos trabalhadores, o fato de que náo conseguiram se tornar patrôes provaria o uso insatisfatório da razão. Com o passar do tempo, a ordem liberal "sanou" boa parte dessas exclusões, incorporando formalmente mulheres e não proprietários à cidadania política, mas essa inclusão não anula o fato de que o cidadâo abstrato, pressuposto pelas instituições, sempre foi o homem burguês. ${ }^{2}$

O terceiro problema, enfim, está ligado ao caráter conjectural do consentimento. Mesmo que se aceite a ficção do pacto originário, ele não vincularia as geraçóes subsequentes. Pateman mostra a inadequação dos dois grandes eixos de resposta à questão. Há soluçóes baseadas no que ela chama de "voluntarismo hipotético" (Pateman, 1985 [1979], p. 16), que nasce já com Locke: ao aceitar os benefícios da vida social (por exemplo, desfrutando do direito de propriedade ou da segurança pública, ou simplesmente usando uma estrada), o indivíduo tacitamente aderiria ao contrato. A inversão nos termos da "arquitetura da escolha", que faz da adesão ao contrato o comportamento padrão (uma vez que estamos cercados pelos frutos da vida social) e exige um esforço de quem deseje não participar dele, desnuda o caráter não voluntário da obrigação política.

A outra resposta é o voto. Ao participar do processo eleitoral, cada cidadão estaria afirmando seu comprometimento com a ordem política em geral. Para além dos problemas banais com essa ideia não é possível derivar a obrigação política em uma situação de voto obrigatório, nem afirmar a obrigação dos que se abstêm (Idem, p. 86) -, há o fato de que se assume que o ato de votar implica o consentimento ao sistema político, sem se preocupar em analisar o que o eleitor realmente deseja expressar (por exemplo, caso escolha candidatos revolucionários). Em suma, "desconsiderar a intenção dos votantes é tratar seu voto como um gesto desprovido de significado" (Idem, p. 88).

Assim, os teóricos e cientistas políticos apresentam o "consentimento dos governados" como característica central da democracia liberal, mas não investigam o significado desse consentimento (Idem, p. 81; Pateman, 1989, p. 71). Caso investigassem, teriam de colocar em xeque uma ordem que é marcada simultaneamente pela transferência de poderes e pela desigualdade. Da análise dos problemas da obrigação política resulta a compreensão de que "a crítica que afirma que a maior parte da teoria democrática liberal é uma mera defesa ideológica do status quo é mais fundamental e devastadora do que em geral se supóe" (Pateman, 1985 [1979], p. 5). ${ }^{3}$

$\mathrm{O}$ que a teoria contratualista e, a partir dela, a teoria democrática liberal apresentam como essência da obrigação política é a promessa de obedecer (feita pelo governado ao governante). No entanto, seguindo Rousseau, a autora entende que a promessa de obedecer é inaceitável porque revoga (ou, ao menos, limita) as capacidades que permitem o próprio ato de prometer (Idem, p. 19). Essa crítica aos mecanismos de "submissão voluntária" é um dos eixos centrais de $O$ contrato sexual, em que $\mathrm{Pa}$ teman analisa diferentes procedimentos pelos quais as mulheres são convocadas a consentir "livremente" com a dominação masculina.

\section{O sexo do contrato}

Em $O$ contrato sexual, Pateman indica que, para decifrar a posição do contrato no pensamento liberal, é necessário investigar simultaneamente suas três expressóes principais: o contrato social, o contrato de trabalho e contrato de casamento. ${ }^{4}$ A teoria política dominante, diz ela, deturpa sistematicamente os dois primeiros e ignora o último (Pateman, 1988, p. x). No livro, ela estuda detidamente os contratos de trabalho e de casamento, mas seu objetivo principal é entender qual o papel que a sujeição das mulheres aos homens desempenha no contrato social.

Ela entende que a crítica feita ao contrato, a partir sobretudo da tradição socialista e marxista, é uma crítica focada nos mecanismos de exploração que são muitas vezes revestidos com relaçóes contratuais. Assim, o relato clássico da extração da mais valia é que o trabalhador, desprovido de outras mercadorias para oferecer no mercado, é 
constrangido a vender sua força de trabalho. Mas a força de trabalho é uma mercadoria especial: ela gera mais riqueza do que a necessária para se reproduzir. Levado pela necessidade, o trabalhador aceita um contrato de assalariamento que sacramenta sua exploração: ele vai produzir mais valor do que receberá em pagamento (Marx, 2013 [1867], seção V).

Não há dúvida de que o relato centrado na exploração é relevante. Mas Pateman quer destacar outro aspecto, em geral negligenciado: a subordinação presente no contrato. Seja no contrato de trabalho, seja no contrato de casamento, há o estabelecimento de uma hierarquia pela qual um dos contratantes (o patrão ou o marido) exerce autoridade sobre o outro (o trabalhador ou a mulher). A subordinação é condição necessária para que, tanto no trabalho quanto no casamento, a exploração possa ocorrer (Pateman, 1988, p. 8). Há, aqui, ecos da obra inicial da autora, simpática à democracia industrial: é o exercício de autoridade do patrão que permite que ele obrigue os trabalhadores a jornadas e a um ritmo de trabalho que proporcionam a exploração.

A fórmula do contrato permite a legitimação das relações interpessoais de subordinação porque está assentada no individualismo possessivo. A mulher ou o trabalhador podem abrir mão de uma boa parte de sua autonomia, em troca do salário ou da proteção do marido, porque se julga que são "proprietários de si mesmos" e, portanto, podem alienar direitos como se alienam propriedades externas. Há dois ganchos para críticas aqui. O primeiro é que tais decisóes, vistas como "livres", são frutos de imposiçôes materiais e simbólicas e da ausência de alternativas. Não é à toa que o capitalismo bloqueou sistematicamente todas as formas que os não proprietários tinham de garantir sua própria subsistência, desde o cercamento das terras comunais, ainda no início da Idade Moderna, como forma de forçá-los ao assalariamento. Ou que, nas sociedades marcadas pela dominação masculina, as mulheres solteiras são impedidas de desfrutar da sua liberdade, pela lei ou pelos costumes. ${ }^{5}$

A segunda dimensão da crítica, que é mais central para Pateman e que se inspira em Rousseau, é que náo pode ser aceito um contrato que, ainda que livremente acordado, retira de uma das partes a liberdade que era condição para seu próprio estabelecimento. Pensadores ultraliberais, que estendem ao máximo o princípio do individualismo possessivo, afirmam posição contrária. Para eles, a liberdade precisa incluir o direito de se vender como escravo (Nozick, 1974, p. 331). Afinal, como dizia outro autor da corrente, "os únicos direitos humanos [...] são direitos de propriedade" (Rothbard, 2006 [1970], p. 291). A distinção entre o indivíduo e suas propriedades externas é apagada.

É claro que a maior parte dos autores, sobretudo no contratualismo contemporâneo, recusa a linguagem da alienação de direitos. É a defesa aberta da alienação de direitos que faz com que, para Samuel Freeman (2002) como para Susan Okin (1990), o libertarianismo à la Nozick seja considerado uma doutrina alheia ao liberalismo. Para Pateman, o ponto é outro. Contratos que envolvem a submissão pessoal implicam a restrição efetiva ao exercício de direitos. Posso mantê-los nominalmente, mas estou numa posição em que careço de autonomia para ativá-los, estando sob o arbítrio de outrem. É o caso do trabalhador (de ambos os sexos) no contrato de emprego e da mulher no matrimônio tradicional. Há uma efetiva, ainda que não declarada, alienação de direitos.

A questão importante, para Pateman, é compreender a dubiedade envolvida na noção, que remonta a Locke, de que cada indivíduo possui uma propriedade em sua própria pessoa. Por um lado, é uma noção que permite avançar na defesa de direitos individuais dos trabalhadores e das mulheres. "Marx não poderia ter escrito $O$ capital e formulado o conceito de força de trabalho sem ela", assim como ela encoraja "muitas campanhas feministas, do passado e do presente, de tentativas de reformar a legislação do casamento e de obter cidadania até demandas pelo direito de aborto" (Pateman, 1988, pp.13-4). Por outro lado, a noção de propriedade de si mesmo legitima formas de abdicação de direitos e de subordinação, impedindo que se avance na crítica à sociedade presente. Sem romper com ela, Marx não teria chegado à denúncia da alienação sob o capitalismo. E tampouco - o que é crucial para o desenvolvimento do restante do livro -o feminismo não seria capaz de questionar a construção do "indivíduo" liberal, à imagem e semelhança do 
homem proprietário. Portanto, não seria capaz de colocar em xeque a "construção patriarcal da feminidade"6 (Idem, p. 15).

Para entender esse processo, é necessário recontar a história do contrato social. As narrativas canônicas do contratualismo dos séculos XVII e XVIII contam que os seres humanos partiriam de um hipotético estado de natureza, em que não havia hierarquia e todos eram livres e iguais. No entanto, tal estado era ruim, impedindo que houvesse segurança e progresso (para Hobbes, Locke e Kant), ou instável, caminhando rumo à própria dissolução (para Rousseau). Assim, as pessoas no estado de natureza percebem que é necessário que elas se associem, formando uma comunidade e, dentro dela, estabelecendo formas de exercício da autoridade, de uma maneira que varia de pensador para pensador. Para todos eles, porém, as mulheres estão ausentes do pacto de associação, seja em razão de sua inferioridade natural (segundo Locke, Rousseau e Kant), seja por motivos circunstanciais (segundo Hobbes, para quem, originalmente igual ao homem, a mulher se fragiliza ao assumir a responsabilidade pelos filhos).

É característico da teoria política tradicional que essa exclusão das mulheres seja vista como algo contingente. Se alguns preconceitos sâo superados e passamos a entender que elas devem ter acesso à cidadania plena, basta retirar a cláusula que as proscreve e o resto do modelo continua inalterado. Nem é preciso ficar na Idade Moderna para observar o fenômeno; ele aparece em autores centrais da filosofia política contemporânea. Jürgen Habermas (1984 [1962]) anotou a ausência das mulheres de sua esfera pública idealizada, mas não julgava que tivesse maiores implicaçôes, o que foi criticado por feministas (Fraser, 1992). O mais importante autor neocontratualista, John Rawls (1971), fazia sua imaginária "posição original" ser monopólio dos "chefes de família". Aceitando a crítica de autoras feministas (Okin, 1989), adicionou explicitamente a igualdade de gênero a seu ideal normativo, sem julgar que ela promovesse alteraçóes substantivas na proposta (Rawls, 2001).

Ou seja: para os contratualistas, a diferença sexual era politicamente relevante, uma vez que embasava a exclusão das mulheres. $\mathrm{Na}$ resposta a tal posição, manifesta-se a tendência de transformar a diferença sexual e também a esfera privada em questōes politicamente irrelevantes (Pateman, 1988, pp. 3, 6 e 17). Com isso, perde-se a compreensão de como a diferença sexual é presente e ativa nas instituiçóes e nas formas de pensar o mundo político. Anulá-la permite superar as exclusôes formais, mas não enfrentar os mecanismos excludentes informais, atuantes nas práticas correntes.

Trata-se, então, de entender que o contrato sexual, que determina a sujeição das mulheres aos homens, é indissociável do contrato social, que cria uma sociedade em que esses homens seráo pretensamente livres e iguais:

A dominação dos homens sobre as mulheres e o direito dos homens de desfrutar de igual acesso sexual às mulheres estáo em questáo na produçáo do pacto original. O contrato social é uma história de liberdade; o contrato sexual é uma história de sujeição. $\mathrm{O}$ contrato original constitui tanto a liberdade quanto a dominação. A liberdade dos homens e a sujeição das mulheres são criadas por meio do contrato original - e a natureza da liberdade civil náo pode ser entendida sem a metade faltante da história, que revela como o direito patriarcal dos homens sobre as mulheres é estabelecido por meio de contrato (Idem, p. 2).

Pateman lê a teoria do contrato como uma atualização da ideologia do patriarcado, adaptada a circunstâncias políticas renovadas. $\mathrm{O}$ termo, que no discurso corrente aparece muitas vezes como um sinônimo para "dominação masculina", possui um sentido preciso na história das ideias, o que levou muitas feministas a contestarem seu uso para descrever as sociedades contemporâneas. Nem o patriarcado como forma de organização política (remetendo a um absolutismo que entendia a nação como dotada de vínculos orgânicos similares aos que existiriam nas famílias), nem o patriarcado como forma de organização doméstica (que supóe uma família que incorpora mais de uma geração e também um contingente de agregados e serviçais, sob o domínio incondicional do patriarca) correspondem ao mundo atual. 
Nas palavras de Jean Bethke Elshtain, a "sociedade capitalista avançada e pluralista está tão distante dos contornos do caso paradigmático [do patriarcado] que rotular a ambos como 'patriarcal' é embaralhar e distorcer a realidade" (Elshtain, 1993 [1981], p. 215). Da mesma forma, seria enganador estabelecer uma equivalência entre o modelo atual de família nuclear vigente no Ocidente, em que marido e mulher estão formalmente em situação de maior equilíbrio (sobretudo com a derrubada, ao longo do século XX, dos diplomas legais que determinavam a autoridade masculina), da família patriarcal propriamente dita. Em vez de buscar uma essência invariável, que a ideia de patriarcado expressaria, é mais útil entender como a dominação masculina é capaz de subsistir mesmo quando as formas que adotava são substituídas. ${ }^{7}$

Nas sociedades ocidentais contemporâneas, as relaçóes de subordinação direta de uma mulher específica a um homem específico, que eram características do patriarcado histórico, foram substituídas em grande medida por formas coletivizadas de dominação. São estruturas impessoais que distribuem vantagens e oportunidades, em prejuízo do gênero feminino (Okin, 1989, pp. 138-139). Com as mudanças no casamento, ele tampouco se adequa ao modelo de autoridade absoluta do marido. É mais adequado defini-lo como uma "parceria desigual", em que as mulheres estão em posição de desvantagem (Fraser, 1997, p. 229).

Por isso, essas autoras feministas preferem entender o patriarcado apenas como uma manifestação histórica específica de um fenômeno mais perene e abrangente, a dominação masculina - mais ou menos como, para o marxismo, "feudalismo" ou "capitalismo" são expressôes historicamente circunscritas da dominação de classe. O paralelo é "mais ou menos" porque, na percepção marxista, as classes dominantes variam de modo de produção para modo de produção, ao passo que na dominação masculina há uma maior continuidade: os homens estâo sempre no polo dominante e as mulheres, no dominado.

Contra tais críticas, é possível defender a pertinência do conceito de patriarcado de dois modos diferentes. O primeiro, banal, é ignorar a questão da precisão ou imprecisão histórica e afirmar a necessidade política de seu uso, como ferramenta retórica. A própria Pateman não se furta a tal caminho, afirmando que "se o problema não tem nome, o patriarcado pode facilmente deslizar de novo para a obscuridade, sob as categorias convencionais da análise política” (Pateman, 1988, p. 20). A posição é expressa com maior franqueza ainda por Michèle Barrett, ao explicar por que recuou de sua crítica anterior à aplicação do conceito de patriarcado à sociedade contemporânea. Mesmo que haja um erro do ponto de vista histórico, permanece o valor de um uso "simbólico", que serve para afirmar "o caráter independente da opressão das mulheres e evitar explicaçóes que a reduzam a outros fatores" (Barrett, 1988b, p. XIII).

O segundo caminho é uma defesa da validade intrínseca do conceito para apreender a dominação masculina contemporânea. Para trilhá-lo, Pateman produz uma reinterpretação da história do pensamento patriarcal, que ela periodiza entre três etapas. O patriarcado tradicional estabelece uma analogia entre a autoridade na família e a autoridade no Estado. A família é tanto uma metáfora da sociedade política quanto sua origem, já que o Estado seria o resultado da união de muitas famílias (Pateman, 1988, pp. 23-24). Tal relação é reforçada na segunda etapa, que ela chama de patriarcado clássico e que estabelece não uma mera analogia, mas uma identificação completa entre o poder do pai e o do governante.

A maior expressão do patriarcado clássico surgiu no século XVII, no livro Patriarcha, obra póstuma de Robert Filmer. Seu objetivo era justificar o poder absoluto do rei da Inglaterra, o que ele faz derivando a autoridade política diretamente da autoridade paterna e do direito de primogenitura. De maneira simplificada, o argumento é o de que Deus concedeu a Terra a Adão, que a legou como herança a seu filho primogênito. O monarca inglês seria o primogênito dos primogênitos de Adão, governando seus súditos da forma irrestrita como o patriarca governa sua casa: "O pai de uma família governa sem outra lei que sua vontade, não pelas leis ou vontades de seus filhos ou serviçais" (Filmer, 1991a [1680], p. 35). Sem ser o pai dos súditos, o rei deve ser entendido como se o fosse; daí a conclusão de que o absolutismo é o único regime político apropriado. 
Quando Filmer escrevia, o absolutismo já estava derrotado como ideia política. A pá de cal foi jogada por John Locke, que dedicou seu Primeiro tratado sobre o governo civil a responder ao Patriarcha. Para Pateman, nesse momento se estabelece também a doutrina do patriarcado moderno, que é definido não pela soberania de um indivíduo, mas pela igualdade entre os homens e sua soberania coletiva sobre as mulheres. Tal movimento tende a ser ignorado porque "a interpretação patriarcal do 'patriarcado"” (Pateman, 1988, p. 27) vê nele uma relação de autoridade do pai sobre os filhos, deixando de lado a relação prévia e necessária de submissão da mulher ao marido. Isto é, a interpretação do patriarcado como direito paterno oculta o contrato de casamento anterior e a relação entre homens e mulheres que ele determina.

No entanto, tal relação é crucial para que o patriarcado se estabeleça. Não é à toa que, em sua polêmica contra o outro grande teórico inglês do absolutismo, Thomas Hobbes, Robert Filmer faça questão de assinalar que a mulher nunca foi igual ao homem. A soberania dele sobre ela seria natural, determinada pelo fato de ele ser "o agente mais nobre e principal na geração" (Filmer, 1991b [1652], p. 192). A igualdade entre os sexos é descartada desde o início, com base em suas características intrínsecas e não em padróes menos ou mais adequados de distribuiçáo social do poder. Para Pateman, uma leitura atenta de Filmer deixa claro que, em sua teoria, a "gênese do poder político reside no direito sexual ou conjugal de Adão, não em sua paternidade. $\mathrm{O}$ direito político está garantido antes de ele se tornar um pai” (Pateman, 1988, p. 87).

Em suma, ao reler a teoria patriarcal tradicional e clássica, Pateman estabelece um processo em três passos. Há a submissão da mulher ao homem, por intermédio do contrato de casamento. Esse passo costuma estar apenas implícito nessas formulações teóricas. O segundo passo é a submissão dos filhos aos pais, determinada pelo modelo familiar patriarcal. Essa submissão aparece como fonte metafórica ou factual para a autoridade monárquica, o que corresponderia ao terceiro passo. Os teóricos antiabsolutistas do contrato impugnam o terceiro passo. Para fazê-lo, limitam o alcance do segundo: a autoridade paterna só vigora enquanto os filhos não adquiriram o pleno uso da razão. Em suma, nós "nascemos livres, assim como nascemos racionais; não que tenhamos de fato o exercício de uma coisa ou outra: a idade que traz uma traz também a outra” (Locke (1998 [1698], p. 437, grifo suprimido).

O primeiro passo, porém, permanece intocado. Mary Wollstonecraft tomou ao pé da letra a equivalência entre monarquia absoluta e casamento e, evocando a Revolução Francesa, provocou: "O direito divino dos maridos, tal como o direito divino dos reis, pode, espera-se, nessa era esclarecida, ser contestado sem perigo" (Wollstonecraft, 2001 [1792], p. 24). Mas não podia. As reivindicações pelos direitos políticos das mulheres foram silenciadas; o triunfo dos regimes liberais, a partir do século XVIII, marcou não a superação do patriarcado, mas, nos termos de Pateman, a emergência de sua encarnação moderna.

Trata-se de um ordenamento social em que se garante tanto a igualdade entre os homens quanto a submissão coletiva das mulheres (sem que isso implique a destruição do padrão de subordinação individual no casamento). O patriarcado moderno prescinde da figura do pai: é um patriarcado "fraternal". Seguindo alguns outros estudiosos do contrato, Pateman inclui a teoria social de Sigmund Freud como uma versáo tardia da corrente - e uma em que a passagem para o patriarcado fraternal é particularmente clara. Em Totem e tabu e em Moisés e o monoteísmo, o criador da psicanálise indica como momento crucial da história humana aquele em que se sai da horda primitiva, na qual o pai primitivo monopolizava as mulheres (e que, para Pateman, é o equivalente ao estado de natureza dos outros autores contratualistas). A superaçáo ocorre por meio do assassinato do pai; depois de um breve (e, para Freud, desinteressante) período de direito materno, os filhos, percebendo que nenhum deles poderia ocupar o lugar que era do pai, formam uma espécie de contrato que assegura seu poder fraternal partilhado (Freud, 1997 [1938], 2012 [1913]; Pateman, 1988, pp.103-104).

O cerne da narrativa freudiana é a substituição de um regime de posse de todas as mulheres por um único homem por outro, em que os homens asseguram coletivamente a posse das mulheres. Pateman indica como, para Freud, as mulheres não são 
personagens: são objetos da luta entre os homens. A história começa quando o direito sexual do pai sobre as mulheres já está estabelecido. E ela pergunta: como esse direito se estabeleceu? Se o contrato social nasce de um crime, o parricídio, o contrato sexual não nasceria de outro crime, o estupro (Pateman, 1988, p. 105)? É o que Freud nega, mas essa negação é sintoma da tendência, comum a todo pensamento político pré-feminista, de recusar caráter político à dominação das mulheres. E também da tendência - de que Freud, como bem observa Pateman, é representante destacado - de negligenciar o componente de violência presente em tantas das relaçóes sexuais.

A referência ao estupro foi criticada por muitas comentaristas de Pateman. Ela estaria aderindo à visão de uma parcela do feminismo radical, que julga que as relaçóes heterossexuais nunca ou quase nunca são consensuais (Okin, 1990, p. 662). No entanto, o ponto de Pateman reside muito mais na ambiguidade do consentimento - uma vez que há um deslizamento do sexo consensual para a subordinação na vida conjugal - e no fato de que a dominação patriarcal sobre os filhos se estabelece a partir de uma assimetria prévia entre o marido e a mulher, ignorada pela reflexáo teórica tradicional. Como respondeu Pateman, sem disfarçar a irritação: "Não me ocorreu que alguém pensaria que eu era tấo estúpida a ponto de fazer da 'conquista' ou do 'estupro primário' a base de um livro em que eu discuto que contratos relativos à propriedade na pessoa, uma forma de acordo voluntário, são o mecanismo da subordinação civil moderna” (Pateman, 2007, p. 217).

É correto apontar, porém, que a formulação presente em $O$ contrato sexual dá margem a tais interpretaçôes, que ecoam mesmo em críticas que partem de posições simpáticas a Pateman (cf. Boucher, 2003, p. 35). O paralelo entre o parricídio descrito por Freud e um estupro original, que daria força retórica à argumentação, não contribui para iluminar o fato de que o patriarcado moderno, em particular, se esforça para produzir o consentimento pelo qual as mulheres aceitariam ser subordinadas ao homem. Daí resulta um paradoxo crucial quanto à posição delas no pensamento dos contratualistas. Mulheres são excluídas do contrato social por- que não contam com as competências necessárias para firmá-lo, em particular o uso da razão. Mas, ao mesmo tempo, devem participar do contrato de casamento, que, sem sua anuência expressa, seria uma forma indisfarçada de coerção.

Ou seja, os "teóricos do contrato simultaneamente negam e pressupóem que as mulheres podem firmar contratos" (Pateman, 1988, p. 54). Consideradas naturalmente inferiores, elas ainda assim devem subscrever de forma voluntária a ordem que lhes atribui a posição de inferioridade. Isso porque, como anotou uma comentarista de Pateman, ela percebe que "a livre-escolha é [...], mais que um ideal, a condição sine qua non para a legitimidade e a justeza dos contratos e dos acordos" (Biroli, 2013, p. 97). Ela é, portanto, sempre pressuposta, para que sua ausência não ponha risco a continuidade das relaçóes daí resultantes.

O paradoxo fica claro em especial na argumentação de John Locke, que cabe observar, talvez com um pouco mais de detalhe do que a própria Pateman faz. Locke é um ardoroso defensor da ideia de que o domínio do homem sobre a mulher, na relação conjugal, faz parte da "ordem natural das coisas". No entanto, movido por sua polêmica contra Robert Filmer, ele disputa a interpretação do trecho bíblico usado para justificar a autoridade masculina, em que Deus, ao expulsar Adão e Eva do Jardim do Éden, diz a ela: "Multiplicarei os sofrimentos de tua gravidez, entre as dores darás à luz os filhos, a paixão arrastar-te-á para o marido e ele te dominará" (Gn 3, 16). No trecho, diz ele, Deus "não concede nenhuma autoridade a Adão sobre Eva ou aos homens sobre suas esposas". Mas determina "que ela estivesse submetida ao esposo, tal como vemos que, geralmente, as leis da humanidade e os costumes das nações assim deliberam; e existe, admito-o, fundamento para tal na natureza" (Locke, 1998 [1698], p. 249).

O objetivo de Locke é refutar a ideia de que Adão recebeu um mandato divino para exercer autoridade sobre toda a Criação, mas é notável a ambiguidade de sua reflexão sobre as relaçóes entre os sexos. Não é o marido que recebe o direito de mandar: é a mulher que recebe a obrigação de obedecer. Tal obrigaçáo tem fundamento na natureza e na vontade de Deus, mas, como o trecho do Gênesis 
deixa claro, é estabelecida por um ato da própria mulher ("a paixão arrastar-te-á para o marido").

São, portanto, dois pontos de ambiguidade. $\mathrm{O}$ primeiro se vincula à ausência de espelhamento entre o direito de uns e os deveres dos outros, que é funcional para a acomodação entre princípios que se deseja manter e práticas que náo os respeitam. Pateman cita William Blackstone, importante autor liberal do século XVIII, explicando que, como a Inglaterra não admite a escravidão, um escravo que ingresse em seu território torna-se imediatamente um homem livre, mas isso não quer dizer que a obrigação perpétua de servir a seu senhor esteja rompida (Pateman, 1988, p. 145). Isso permite combinar a regra da igualdade natural com a manutenção da subordinação do escravo, assim como, na interpretação que faz do Gênesis, Locke pode distinguir a família da autoridade política, sem com isso comprometer a dominação do marido.

O segundo elemento de ambiguidade está no fato de que algumas pessoas precisam dar seu aval para as relaçôes de subordinação às quais já estão naturalmente destinadas, como é o caso das mulheres e dos trabalhadores (de ambos os sexos). Há uma contradição evidente entre "os pressupostos da teoria do contrato e os apelos à força [física e mental] natural" (Idem, p. 94). A legitimidade da relação contratual se baseia no entendimento de que as partes são igualmente capazes. Se mulheres e trabalhadores são inferiores por natureza, seu engajamento em relaçóes contratuais é tanto desnecessário quanto incapaz de dotar tais relações da legitimidade pretendida.

Os contratos de casamento e de trabalho estabelecem relações de subordinação entre indivíduos específicos, assim como os pretensos contratos sexual e social originários criam narrativas que sustentam a subordinação das mulheres aos homens e dos governados aos governantes. O paradigma de todas essas relações é a escravidão, que um autor contratualista do século XVII, Samuel von Pufendorf, também julga que pode ser fruto de acordo voluntário entre as partes. ${ }^{8}$ Para Pateman, os argumentos de Pufendorf são úteis por desvelar a conexão entre a ideologia do contrato, o individualismo possessivo e a justificação da dominação.

Um trecho da obra principal do jurista alemão serve de exemplo suficiente. Após apresentar a es- cravidão como "servidão perpétua voluntária", ele diz que

[...] em toda parte se admite que a Prole de Pais que são Escravos encontra-se também em uma Condição servil, e pertence como Escravos ao Dono de sua Mãe. O que se justifica por esta Máxima: que Quem é Proprietário do Corpo é também Proprietário de qualquer Produto desse Corpo, e porque essa Prole nunca teria nascido se o Senhor houvesse feito valer o Rigor da Guerra sobre o Genitor; e como a Mãe nada tem que possa chamar de seu próprio, sua Cria, de resto, não pode ser criada senão a cargo de seu Senhor (Pufendorf, 2007 [1673], p. 279).

Isto é, levada a seu grau máximo, a doutrina do individualismo possessivo justifica mesmo a escravidão hereditária. Nascida para afirmar a autonomia de cada indivíduo, ela acaba por permitir "que a oposição entre liberdade e escravidão seja dissolvida" (Pateman, 1988, p. 66). Escravidão, assalariamento e casamento são, assim, três formas de subordinação que contratos contribuem para disfarçar. E que, prévias ao contrato social da narrativa liberal, permitem que trabalhadores de ambos os sexos e mulheres de todas as classes sociais sejam excluídos da cidadania.

\section{O patriarcado, hoje}

Pateman tem sucesso ao indicar de que forma a dominação sobre as mulheres é uma etapa necessária, mas oculta, do patriarcado político. Sua descrição de como, na ideologia predominante, a autoridade individual do patriarca é substituída pela autoridade coletiva de todos os homens também é convincente. Ainda assim, resta polêmica sobre a caracterização da sociedade contemporânea como patriarcal. Na própria teoria de Pateman, o conceito permanece ancorado numa desigualdade brutal e escancarada de direitos na relaçáo conjugal. Como visto, o fato de esta não ser mais uma descrição adequada das sociedades ocidentais leva autoras feministas a descartar o rótulo. As mulheres obtiveram acesso à educação, à propriedade e ao voto; cada vez 
mais, a legislação define o casamento como uma parceria entre iguais, eliminando as cláusulas que garantiam a primazia do marido. É claro que permanecem assimetrias muito fortes - nenhuma autora feminista negaria o fato. Mas um casamento no final do século XX já era muito diferente de um casamento no início do mesmo século, para não dizer no auge do patriarcado clássico (cf. Biroli, 2014).

Numa crítica aprofundada a Pateman, Nancy Fraser afirma que ela lê as relaçóes de gênero como uma relação entre senhor e súdita - o que está longe de ser apropriado para o mundo contemporâneo (Fraser, 1997, p. 225). Mesmo o ambiente social que forçava a mulher ao casamento, permitindo o paralelo inconteste com a privação que obriga o trabalhador a se assalariar, sofreu transformação. Ainda há dependência econômica da mulher, preconceitos contra as que permanecem solteiras e uma ideia difusa de que elas estão carentes de proteção. Mas não é possível equivaler essa situação à dos séculos XVIII ou XIX, ou à das primeiras décadas do século XX. Ou seja, "os sentidos atuais de gênero, sexo e sexualidade são altamente fragmentados e contestados. Os sentidos inscritos no contrato sexual de Pateman são apenas um componente da mistura" (Idem, p. 229). A própria Pateman reconhece, nas últimas páginas do livro, que "as estruturas e divisões patriarcais não são mais tão sólidas quanto foram" (Pateman, 1988, p. 233), mas não desenvolve o ponto. ${ }^{9}$

$\mathrm{O}$ apego à noção do contrato sexual e do patriarcado moderno impediria, dessa forma, uma compreensão clara da maior complexidade da dominação masculina nas sociedades contemporâneas. Uma tentativa de resolver o problema está na obra de Silvia Walby, que julga crucial preservar o conceito, único capaz de "capturar a profundidade, penetração ampla [pervasiveness] e interconectividade dos diferentes aspectos da subordinação das mulheres" (Walby, 1990, p. 2). É possível lê-la como um acréscimo à narrativa de Pateman, seja de uma etapa posterior ao patriarcado moderno, seja de uma transformação dentro dele: a passagem do "patriarcado privado" ao "patriarcado público". Nesse último, as mulheres têm acesso à esfera pública, mas permanecem em posição subordinada dentro dela. "A expropriação das mulheres ocorre mais de for- ma coletiva do que por patriarcas individuais. O lar permanece um espaço de opressão patriarcal, mas não é mais o principal local em que mulheres estão presentes" (Idem, p. 178).

O problema com o conceito de "patriarcado público" é que ele se distancia em excesso do sentido estabelecido de patriarcado. O patriarcado moderno de Pateman já havia abolido a figura do patriarca; o patriarcado público afasta também a vinculação com a organização familiar. Ademais, é malograda a tentativa de Walby de descrever o patriarcado como um sistema estruturado, que age sobre os diferentes espaços da vida social, de forma similar à do capitalismo. Sua própria argumentação apresenta uma descrição de padrôes diferenciados de dominação masculina, que estão sempre presentes e atuantes, mas respondem a dinâmicas diversas e agem por meio de mecanismos também diversos em cada espaço social (Pollert, 1996).

Outro flanco de crítica está no entendimento das relaçóes contratuais, que na leitura de Pateman seriam excessivamente desequilibradas ou mesmo unilaterais. É verdade que para o feminismo, como para o socialismo, é central a denúncia feita à ideia de que contratos são, por definição, voluntários e mutuamente vantajosos. Aceitar tal ideia é negar o peso que as desigualdades sociais têm na capacidade diferenciada de os agentes exercerem sua autonomia e, portanto, o fato de que alguns, pela falta de recursos e de alternativas, são levados a assumir contratos que beneficiam muito mais a outros. Mas isso não significa entender que os que estão em posição mais vulnerável não possuem nenhuma capacidade de negociação ou não são capazes de extrair qualquer vantagem das relaçóes contratuais em que se inserem. ${ }^{10}$

Nancy Fraser apresenta o exemplo hipotético, mas fundado na realidade, de uma jovem solteira que deixa a fazenda, "com seu horário de trabalho indeterminado, supervisão permanente dos pais e pouca vida pessoal autônoma” (Fraser, 1997, p. 230), por uma cidade industrial, em que o controle estrito na fábrica se combina à autonomia ampliada fora dela, em que ela é dona do próprio nariz e possui seu próprio dinheiro para gastar. "De sua perspectiva, o contrato de trabalho foi uma libertação" 
(Idem). Isto é, as circunstâncias devem ser levadas em conta náo só para questionar a ideia de que os contratantes estáo em posição equivalente, mas também para entender qual o impacto que a relação contratual, mesmo assimétrica, exerce na vida das pessoas. $\mathrm{O}$ contrato de trabalho estabelece uma subordinação, como diz Pateman, mas tal subordinação, circunscrita à jornada laboral que o próprio contrato estabelece, pode ser um avanço em relação à exploração do trabalho na esfera familiar, em que a autoridade paterna (e materna) é basicamente ilimitada.

Um exemplo adicional é a prostituição. $\mathrm{Na}$ visão de Pateman, o contrato estabelecido entre a prostituta e seu cliente sintetiza as assimetrias e as vulnerabilidades de trabalhadores e mulheres, presentes no contrato de trabalho e no contrato de casamento. É a expressão maior da ideia de que a pessoa é uma propriedade que pode ser transacionada e a mais clara forma de institucionalização da subordinaçáo de um ser humano a outro. $\mathrm{O}$ contrato garantiria ao cliente acesso unilateral e ilimitado ao corpo da prostituta; o único critério para avaliação do serviço prestado seria sua própria satisfação. E, sobretudo, no contrato de prostituição não há sequer o fornecimento de proteção, que, nos contratos de trabalho e casamento, é a contrapartida da obediência (Pateman, 1988, pp. 208-209). ${ }^{11}$

Mas Nancy Fraser julga que é equivocado entender o contrato de prostituição nos moldes - uma vez mais - de uma relação entre senhor e súdita. Ao contrário do que diz Pateman, as profissionais do sexo impóem limites e negociam com seus clientes como será sua performance. Elas vendem "uma fantasia masculina do 'direito sexual masculino', que implica a sua precariedade no mundo real. Mais do que adquirir comando sobre a prostituta, o que o cliente recebe é uma encenação deste comando" (Fraser, 1997, p. 233). Isto é: o contrato impóe a subordinação, mas também determina seus limites.

Críticos de Pateman condenaram também sua recusa liminar à ideia de contato social. Por exemplo, Susan Okin, em sua resenha, apresenta uma série de questionamentos à estratégia argumentativa do livro, mas o ponto central é que seria errôneo condenar todos os contratos como ilegítimos. Segundo ela, "Pateman desiste fácil demais dos usos do contrato para o feminismo" (Okin, 1990, p. 666). O projeto de Okin, afinal, é caminhar na direção de uma releitura do contrato, a partir da variante rawlsiana, que permita apropriá-lo na fundamentação de uma sociedade igualitária no que diz respeito aos sexos. Sem chegar a construir tal modelo, Okin (1989) aposta que a inclusão da família entre as estruturas que devem ser regidas pelos princípios da justiça permitiria fundar normativamente a igualdade de gênero.

Mas a discussão mais aprofundada foi estabelecida por Charles W. Mills, que se inspirou em Pateman para desenvolver sua ideia de um "contrato racial". Pateman mesma observou que o contrato social possui uma dimensão racista, que ela não analisava em seu livro (Pateman, 1988, p. 161). Mills parte daí e indica como, no início da Idade Moderna, os europeus pactuaram entre si a divisáo do mundo e seu direito de governar os não brancos. Da mesma forma que o contrato sexual, estabelecido por homens sobre as mulheres, é pactuado "entre aqueles caracterizados como brancos sobre os não brancos, que assim são os objetos antes que os sujeitos do acordo" (Mills, 1997 , p. 12). Mas, ao contrário do contrato social na tradição filosófica dominante ou do contrato sexual de Pateman, o contrato racial de Mills remete a um conjunto de eventos históricos efetivos, que estão na raiz da dominação europeia sobre todo o planeta e da consequente subjugação dos povos náo brancos (Idem, p. 20). Em sua dimensão "epistemológica", o contrato garante a permanência de uma hierarquia racial que faz com que, de maneira sistemática, os brancos tenham privilégios e suas vidas sejam consideradas mais valiosas.

No entanto, Mills julga que é possível diferenciar o "contrato de dominação", que estabelece a subordinação de trabalhadores, mulheres e não brancos, de um modelo contratual marcado pelo respeito mútuo e simétrico a todos. Sua posição "não vê os ideais do contratualismo em si mesmos como necessariamente problemáticos, mas mostra como eles foram traídos pelos contratualistas brancos" (Idem, p. 129). O erro de Pateman seria julgar que a variável hobbesiana do contrato é a única possível. $\mathrm{O}$ contrato kantiano não presumiria o individualismo possessivo; ao contrário, seria marcado pelo imperativo categórico de garantir a autonomia de todos os "fins últimos em si mes- 
mos", isto é, os seres humanos, caracterizados por seu igual valor moral (Idem, pp. 84 e 86). Fica claro que, na visão de Mills, as desigualdades afirmadas por Kant como naturais, que fazem com que ele julgue expressamente que mulheres e não brancos são inferiores, seriam acessórias. Seria possível limpar sua teoria de tais elementos e permanecer com uma visão normativamente íntegra e igualitária.

Tais observações não são pertinentes para $\mathrm{Pa}$ teman porque ela parte de uma crítica muito mais radical às instituiçóes vigentes, fundada numa visão emancipatória mais rigorosa - ou talvez, diriam alguns, mais irrealista. Como ela observa em seu diálogo com Charles Mills, que é o capítulo inicial do livro conjunto The contract and domination, o contrato tem um lugar valioso nas transaçóes comerciais, mas estabelecer toda a cooperação social nesses moldes é "ver os indivíduos como pacotes de propriedade alienável, [...] uma visão muito estreita dos seres humanos e do que eles criam" (Pateman e Mills, 2007, p. 15). No momento em que a "mercantilização está avançando a uma taxa extraordinariamente rápida $[\mathrm{e}]$ já não há virtualmente nada que tenha ficado fora do alcance da propriedade privada, do contrato e da alienaçáo" (Idem, p. 14), é necessário resistir a tal discurso.

Criticando Pateman, Wendy Brown diz que ela investe contra um espantalho (um "fetiche", em suas próprias palavras), uma vez que, no liberalismo contemporâneo, as funçôes de legitimação não se apoiam mais na linguagem do contrato, mas no discurso dos direitos (Brown, 1995, p. 138). Ainda que não se conteste o veredito (é possível argumentar que a invocação legitimadora do contrato não está tâo morta assim), cabe lembrar que o esforço de Pateman foi também mostrar como o discurso contemporâneo dos direitos depende da noção da pessoa como proprietária de si mesma (Gatens, 2008, p. 41). É essa concepção, uma visão antropológica decalcada do Homo economicus gerado pelo capitalismo, que é, no final das contas, o grande alvo de Pateman.

Charles Mills pode dizer que, na ausência de alternativas, sua denúncia do contrato racial apostaria num "capitalismo não supremacista branco", que ao menos fizesse jus "à sua publicidade de 'sociedade aberta aos talentos'” (Pateman e Mills, 2007, p. 31).
Pateman certamente não. Seu feminismo é indissociável do compromisso com uma sociedade diferente, com pontos de contato com aquela esboçada pelo socialismo antiautoritário e pelo ecologismo autonomista de André Gorz (1988) - um autor que, no entanto, foge a seu repertório.

É esse compromisso que dá rumo a toda a obra de Pateman, cujo principal esforço, então, é contribuir para desnaturalizar as instituições, revelando padrỗes de dominação subjacentes a elas. A emancipação feminina é parte essencial desse programa; por isso, como disse ela, "uma teoria e prática 'democrática' que não é ao mesmo tempo feminista serve apenas para manter uma forma fundamental de dominação e assim zomba dos ideais e valores que a democracia busca encarnar" (Pateman, 1989, p. 223). Ao propor uma interpretaçáo sofisticada da relação entre a dominaçáo masculina e as noçóes de contrato e consentimento que estão na base dos regimes políticos ocidentais, ela contribuiu decisivamente para avançar nessa direção, tornando o feminismo componente inextricável de qualquer reflexão sobre a democracia digna de seu nome.

\section{Notas}

1 A pioneira foi a Nova Zelândia, em 1893. Os casos mais gritantes de retardo foram Suíça (1971) e Liechtenstein (1984, com restrições).

2 Além, é claro, de branco. Os não brancos estão ausentes da discussão de Locke. É possível pensar, como faz um comentarista, que essa exclusão, associada ao fato de que o filósofo inglês se opunha à escravidáo mas investia em empresas de tráfico negreiro, indica que "Locke via os negros como não inteiramente humanos e portanto sujeitos a um conjunto diferente de regras normativas" (Mills, 1998, p. 68).

3 Pateman defende um modelo inspirado em Rousseau, que privilegia a obrigação política horizontal, entre os cidadãos, em vez de vertical, com os governantes. A concordância dos cidadãos seria ratificada cotidianamente, por meio da participação permanente na comunidade política (Pateman, 1985 [1979], p. 152). Ou seja: embora seja tecnicamente um "contratualista”, Rousseau é aceito por Pateman como uma de suas inspiraçóes porque seu contrato social náo implica abdicação (como em Hobbes) ou delegação (como em Locke), mas sim 
a participação permanente no exercício da soberania. Não há como desenvolver o ponto aqui.

4 Falando sobre o livro, ela enfatiza que seu tema é tanto gênero quanto classe (Pateman, 2007, p. 13). A crítica ao contrato de trabalho é táo central ao argumento quanto a crítica ao contrato de casamento.

5 Um exemplo literário eloquente está no romance Retrato de uma senhora, de Henry James (1995 [1881]). Isabel Archer, a protagonista, é uma jovem que recebe uma grande herança e decide usá-la para conhecer o mundo. Mas regras legais, preconceitos e formas de violência tornam inviável que, na segunda metade do século XIX, mesmo uma mulher solteira rica desfrute de sua fortuna. Ela se vê forçada, então, a abrir mão de seus sonhos, arranjar um marido e aceitar seu comando.

6 No original, womanhood. Optei por usar "feminidade" como tradução, indicando o "ser mulher" de maneira mais neutra, e traduzir "femininity" por "feminilidade", indicando o conjunto de estereótipos vinculados aos papéis sexuais femininos.

7 Para outra autora crítica à utilização do conceito de patriarcado, o entendimento de que a dominação masculina é invariável, insensível à transformação histórica, levaria a entendê-la como fundada nas diferenças biológicas entre mulheres e homens (Barrett, 1988a [1980], pp. 12-4) - posição que a maioria das feministas se esforça por refutar.

8 É o caso também de Hobbes, mas ele é singular ao não escamotear que a violência é a matriz de grande parte das relaçóes contratuais. A originalidade de Hobbes - teórico do absolutismo que advogou tanto a origem popular do poder quanto a primazia dos interesses individuais, sendo fonte do pensamento democrático e do pensamento liberal - faz com que sua posição, entre os contratualistas, seja sempre especial (Miguel, 2015, cap. 5).

9 Em resposta a seus críticos ela é bem mais enfática, afirmando que observara que as estruturas patriarcais "estavam já começando a se desfazer" (Pateman, 2007, p. 228).

10 Uma resposta banal à posição de Pateman diria que os contratos descritos pelos contratualistas são hipotéticos, não reais, e pressupóem a igualdade entre as partes. Como visto, há aí o equívoco de julgar que a assimetria de recursos é um aspecto contingente, que pode ser abstraído sem prejuízo à economia geral do modelo. E não se leva em conta o papel que a narrativa edulcorada do contrato ideal cumpre na legitimaçáo dos contratos (desiguais) reais.

11 O debate sobre a prostituição opóe uma visão conser- vadora, segundo a qual a venda de sexo ofenderia valores morais e familiares, e outra liberal, para a qual a sociedade não pode intervir em atos consensuais entre adultos. No feminismo, que recusa tanto o enquadramento moral convencional quanto a noção liberal de uma autonomia individual descolada do contexto social, a polêmica é entre defensoras da proibição, como forma de combater o tráfico de mulheres e a exploração sexual, e as advogadas da legalização, que daria recursos para que as profissionais do sexo ficassem em posição menos vulnerável. Para um resumo da discussão no feminismo, ver Miguel (2014).

\section{BIBLIOGRAFIA}

BARRETT, MICHÈLE. (1988A [1980]), Women's oppression today: the Marxistffeminist encounter. Londres, Verso.

. (1988b), "Introduction to the 1988 edition", in Women's oppression today: the Marxist/ feminist encounter. Londres, Verso.

BEAUVOIR, Simone de. (1949), Le deuxième sexe. Paris, Gallimard, vol. 2.

BÍBLIA SAGRADA. (s.d.), Petrópolis, RJ, Vozes, 1982.

BIROLI, Flávia. (2013), Autonomia e desigualdades de gênero: contribuiçóes do feminismo para a crítica democrática. Niterói, RJ, Eduff.

. (2014), Família: novos conceitos. Sáo Paulo, Fundação Perseu Abramo.

BOUCHER, Joanne. (2003), "Male power and contract theory: Hobbes and Locke in Carole Pateman's The sexual contract". Canadian Journal of Political Science/Revue Canadienne de Science Politique, 36 (1): 23-39.

BRENNAN, Theresa \& PATEMAN, Carole (1979), "Mere auxiliaries to the Commonwealth': women and the origins of liberalism". Political Studies, XXVII (2): 183-200.

BROWN, Wendy. (1995), States of injury: power and freedom in late modernity. Princeton, Princeton University Press.

DALY, Mary. (1993 [1973]), Beyond God the father: toward a philosophy of women's liberation. Boston, Beacon Press.

ELSHTAIN, Jean Bethke. (1993 [1981]), Public man, private woman: women in social and poli- 
tical thought. 2. ed. Princeton: Princeton University Press.

FILMER, Robert. (1991a [1680]), Patriarcha: the naturall power of kinges defended against the unnatural liberty of the people, in Patriarcha and other writings. Cambridge, Cambridge University Press.

(1991b [1652]), "Observations concerning the originall of government", in Patriarcha and other writings. Cambridge, Cambridge University Press.

FRASER, Nancy. (1992), "Rethinking the public sphere: a contribution to the critique of actually existing democracy", in Craig Calhoun (ed.), Habermas and the public sphere, Cambridge, MA, The MIT Press.

. (1997), Justice interruptus: critical reflections on the "postsocialist" condition. Nova York, Routledge.

FREEMAN, Samuel. (2002), "Iliberal libertarians: why libertarianism is not a liberal view". Philosophy \& Public Affairs, 30 (2): 105-151.

FREUD, Sigmund. (1997 [1938]), "Moisés, seu povo e a religiāo monoteísta”, in Moisés e o monoteísmo, Rio de Janeiro, Imago. . (2012 [1913]), Totem e tabu, in Obras completas, vol. 11, São Paulo, Companhia das Letras.

FRIEDAN, Betty. (2001 [1963]), The feminine mystique. Nova York, Norton.

GATENS, Moira. (2008), "Paradoxes of liberal politics: contracts, rights, and consent", in Daniel O'Neill, Mary Lyndon Shanley e Iris Marion Young (eds.), Illusion of consent: engaging with Carole Pateman, University Park, PA, The Pennsylvania State University Press.

GORZ, André. (1988), Métamorphoses du travail: quète du sens. Critique de la raison économique. Paris, Galilée.

GREER, Germaine. (1991 [1970]), The female eunuch. Nova York, Harper Collins.

HABERMAS, Jürgen. (1984 [1962]), Mudança estrutural da esfera pública. Rio de Janeiro, Tempo Brasileiro.

JAMES, Henry. (1995 [1881]), Retrato de uma senhora. São Paulo, Companhia das Letras.

LOCKE, John. (1998 [1698]), Dois tratados sobre o governo. São Paulo, Martins Fontes.

MACPHERSON, C. B. (1962), The political theory of possessive individualism: Hobbes to Locke. Oxford, Oxford University Press.

MARX, Karl. (2013 [1867]), O capital: crítica da economia política, livro I. São Paulo, Boitempo.

MIGUEL, Luis Felipe. (2014), "O debate sobre prostituição", in Luis Felipe Miguel e Flávia Biroli, Feminismo e política, São Paulo, Boitempo. . (2015), O nascimento da politica moderna: de Maquiavel a Hobbes. Brasília, Editora da UnB.

MILLETT, Kate. (2000 [1969]), Sexual politics. Urbana, IL, University of Illinois Press.

MILLS, Charles W. (1997), The racial contract. Ithaca, NY, Cornell University Press.

. (2007), "The domination contract", in Carole Pateman e Charles W. Mills, The contract and domination, Cambridge, Polity Press.

NOZICK, Robert. (1974), Anarchy, State, and utopia. Nova York, Basic Books.

OKIN, Susan Moller. (2013 [1979]), Women in Western political thought. Princeton, Princeton University Press.

OKIN, Susan Moller. (1989), Justice, gender, and the family. Nova York, Basic Books.

(1990), "Feminism, the individual, and contract theory". Ethics, 100: 658-669.

PATEMAN, Carole. (1985 [1979]), The problem of political obligation: a critique of liberal theory. Reedição com novo posfácio. Berkeley, CA, University of California Press.

. (1988), The sexual contract. Stanford, Stanford University Press.

. (1989), The disorder of women: democracy, feminism and political theory. Stanford, Stanford University Press.

. (1992 [1970]), Participação e teoria democrática. São Paulo, Paz e Terra.

. (2007), "On critics and contract", in Carole Pateman e Charles W. Mills, The contract and domination, Cambridge, Polity Press.

. (2009 [2002]), "Soberania individual e propriedade na pessoa: democratização e um conto de dois conceitos". Revista Brasileira de Ciência Política, 1: 171-218.

PATEMAN, Carole \& MILLS, Charles W. (2007), 
"Contract and social change: a dialogue between Carole Pateman and Charles W. Mills", in Carole Pateman e Charles W. Mills, The contract and domination, Cambridge, Polity Press.

POLLERT, Anna. (1996), "Gender and class revisited: or, the poverty of 'patriarchy". Sociology, 30 (4): 639-659.

PUFENDORF, Samuel von. (2007 [1673]), Os deveres do homem e do cidadão de acordo com as leis do direito natural. Rio de Janeiro, Topbooks.

RAWLS, John. (1971), A theory of justice. Cambridge, MA, Harvard University Press.

. (2001), Justice as fairness: a restatement. Cambridge, MA, Belknap.

ROTHBARD, Murray N. (2006 [1970]), Power \& market. Auburn, AL, Ludwig van Mises Institute. WALBY, Sylvia. (1990), Theorizing patriarchy. Oxford, Blackwell.

WOLLSTONECRAFT, Mary. (2001 [1792]), A vindication of the rights of woman: with strictures on political and moral subjects. Nova York, The Modern Library. 


\section{CAROLE PATEMAN E A CRÍTICA FEMINISTA DO CONTRATO}

\section{Luis Felipe Miguel}

Palavras-chaves: Teoria democrática; Feminismo; Contrato; Consentimento; Carole Pateman.

$\mathrm{O}$ artigo discute a contribuição de Carole Pateman para a teoria política democrática. A crítica ao instrumento liberal do contrato, presente desde suas primeiras obras, permite entender como relaçóes de subordinação, que reduzem a possibilidade de autonomia dos agentes, transitam de maneira voluntária e consentida. Isso leva Pateman a analisar como a subordinação das mulheres organiza uma ordem política liberal que, no entanto, busca se apresentar como neutra em relação a gênero. Uma análise do enfrentamento de Pateman com seus críticos possibilita observar os limites de sua empreitada teórica, assim como a radicalidade de seu projeto democrático.

\section{CAROLE PATEMAN AND THE FEMINIST CRITIQUE OF THE CONTRACT}

Luis Felipe Miguel

Keywords: Democratic theory; Feminism; Contract; Consent; Carole Pateman.

This article discusses the contribution of Carole Pateman for the democratic political theory. The criticism of the liberal instrument "contract", which is frequent since her early works, allows us to understand how relations of subordination, which reduce the possibility of autonomy for the agents, pass as voluntary and consensual. This leads Pateman to analyze how the subordination of women organizes a liberal political order that seeks to present itself as neutral in relation to gender. An analysis of Pateman's confrontations with her critics permits us to observe the limits of her theoretical work, and also the radical nature of her democratic project.

\section{CAROLE PATEMAN ET LA CRITIQUE FÉMINISTE DU CONTRAT}

\section{Luis Felipe Miguel}

Mots-clés: Théorie démocratique; Féminisme; Contrat; Consentement; Carole Pateman.

L'article aborde la contribution de Carole Pateman à la théorie politique démocratique. La critique de l'instrument libéral du contrat, présente dès ses premières œuvres, nous permet de comprendre comment les relations de subordination, qui réduisent la possibilité d'autonomie des agents, circulent de façon volontaire et consensuelle. Cela conduit Pateman à analyser la manière par laquelle la subordination des femmes organise un ordre politique libéral qui, cependant, cherche à se présenter comme neutre par rapport au genre. Une analyse de la confrontation de Pateman avec ses critiques permet d'observer les limites de son œuvre théorique, mais aussi la nature radicale de son projet démocratique. 